\title{
STUDI KASUS DINAMIKA EMOSI PADA ANAK AUTIS
}

\author{
Riza Noviana Khoirunnisa dan Mochammad Nursalim \\ Universitas Negeri Surabaya \\ e-mail: rizanoviana.icha@yahoo.co.id
}

\begin{abstract}
This study aimed at exploring the emotional dynamics of children with autistic. A qualitative approach with case study method was employed. Two autistic children with average autism severity in Cita Hati Bunda School and Therapy Center for autistic children Sidoarjo were recruited as participants. Data were collected from interviews, observation, and relevant documents. The Plutchik's concept of emotion components, namely stimulus event, inferred cognition, physiological arousal, feeling state, impulse to action, and overt behaviour and effect was used to invoke some psychological insight in the analysis. The study found that the dynamic of emotions that occurs in autistic children was influenced mainly by situational factors. The result suggested that autistic children need more times to perceive the contexts of stimuli. However, this study was not able to explain how these children make meanings of those stimuli.
\end{abstract}

Key words: emotional dynamics, autistic children

\begin{abstract}
Abstrak: Penelitian ini bertujuan untuk mengeksplorasi dinamika emosional pada anak-anak autis. Pendekatan kualitatif dengan metode studi kasus digunakan. Dua anak autis dengan tingkat keparahan autisme rata-rata di Cita Hati Bunda Sekolah dan Terapi Pusat autis anak Sidoarjo direkrut sebagai partisipan. Data dikumpulkan dari wawancara, observasi, dan dokumen yang relevan. Konsep Plutchik tentang komponen emosi, yaitu stimulus event, inferred cogni-tion, physiological arousal, feeling state, impulse to action, overt behaviour dan effect digunakan untuk memberikan wawasan psikologis dalam menganalisis data. Studi ini menemukan bahwa meskipun ketika emosi itu bangkit anak-anak autistik ini tidak mampu mengontrolnya, namun dinamika emosi yang terjadi pada anak autistik sesungguhnya dipengaruhi terutama oleh faktor situasional. Hasil penelitian juga menunjukkan bahwa anak-anak autis perlu waktu yang lebih banyak untuk memahami konteks rangsangan. Namun, penelitian ini tidak dapat menjelaskan bagaimana anak-anak ini memaknai berbagai rangsangan yang mereka terima.
\end{abstract}

Kata kunci: Dinamika emosi, anak autistik

Semua individu merasakan emosi dalam hidupnya. Emosi merupakan reaksi dari individu terhadap individu lain, objek maupun situasi di sekitarnya. Pengungkapan emosi muncul dalam berbagai bentuk, seperti ekspresi wajah, cara perilaku, maupun ucapan secara verbal. Individu normal pada umumnya mampu mengontrol emosi yang muncul dalam dirinya, karena tidak memiliki kelainan dalam struktur otak yang mengatur emosi. Anak autistik dilahirkan dengan keadaan yang "kurang" dari individu normal. Bauman dan Courchense (dalam Cristina M, 2009) menemukan kelainan Susunan Saraf Pusat (SSP) pada beberapa tempat dari anak autistik. Salah satu kelainan itu adalah pengecilan Cerebellum (otak kecil) terutama Lobus VI-VII. Lobus VI-VII berisi sel-sel
Purkinje, yang memproduksi neurotransmiter cerotonin. Pada anak autisme, jumlah sel purkinje sangat kurang, akibatnya produksi serotonin berkurang yang menyebabkan penyaluran rangsang/informasi antar sel otak terganggu. Bentuk kelainan lainnya adalah kelainan pada struktur pusat emosi dalam otak (sistem limbik), yang bisa menerangkan kenapa emosi anak autis sering terganggu.

Anak autistik adalah seorang laki-laki atau perempuan yang berusia dua sampai dua belas tahun yang memiliki sindrom autism yaitu penarikan diri yang ekstrem dari lingkungan sosialnya, gangguan dalam berkomunikasi, serta tingkah laku yang terbatas dan berulang (stereotipik) yang muncul sebelum usia 3 tahun. Anak autistik kesulitan untuk memahami emosi yang ada di 
lingkungannya. Mereka juga memiliki gangguan sensoris, persepsi dan komunikasi yang menyebabkan mereka tidak dapat menyampaikan maupun mengenali emosi yang ada di lingkungannya sehingga perilakunya berbeda dengan individu normal.

Hasil pengamatan awal yang dilakukan di sekolah dan pusat terapi Cita Hati Bunda Sidoarjo pada tanggal 4 Februari 2011 menunjukkan bahwa anak-anak autistik dapat secara tiba-tiba memunculkan emosinya tetapi ia kesulitan dalam mengontrol. Terlebih lagi ia juga kesulitan dalam memahami emosi yang ada di lingkungannya. Selain itu, keadaan emosi anak autistik tidak stabil. Mereka dapat marah tidak terkendali apabila keinginan tidak dipenuhi. Mereka dapat tibatiba tertawa terbahak-bahak atau menangis bahkan menyerang orang lain tanpa didugaduga.

Dinamika emosi tersebut merupakan kaitan antara komponen-komponen emosi yaitu reaksi fisiologis, faktor kognitif dan situasional, perasaan serta perilaku (Haber \& Runyon, 1994). "komponen-komponen emosi tersebut saling berkaitan erat tanpa dapat ditentukan secara pasti urutan kemunculannya" (Davidoff, 2001). Bahon-Cohen et al (dalam Castelli, 2005) menemukan kelemahan yang spesifik pada pengenalan ekspresi terkejut (belief-based expression) dibanding emosi senang dan sedih (realitybased expression). Castelli (2005) juga menemukan bahwa anak dengan autistik dapat mengenali emosi dasar (happines, anger, sadness, surprise, fear, disgust) melalui ekspresi wajah, tidak hanya pada saat mencocokkan gambar ekspresi wajah, tetapi juga saat memberikan nama pada masingmasing ekspresi wajah tersebut. Plutchik (2003) menyebutkan ada enam emosi dasar/ basic emotion yaitu meliputi penerimaan (acceptance), jijik/ muak (disgust), gembira (joy), takut (fear), kesedihan (sadness), dan terkejut (surprise).

Dalam beberapa penelitian mengenai emosi pada anak autis didapatkan beberapa stimulus yang menimbulkan respon emosi adalah benda-benda yang ada di dalam kehidupan mereka sehari-hari (Greenspan dan Wieder, 2006). Ditemukan bahwa bendabenda lebih banyak direspon daripada orangorang yang ada di dalam kehidupannya (Peeters, 2004). Pada saat anak autistik mengalami suatu emosi, penyebab yang mendasari emosi mereka biasanya adalah situasi, benda kesayangan, maupun orang di sekitar. Dengan demikian dinamika emosi pada anak autistik, bukanlah sesuatu yang sederhana namun merupakan suatu proses yang saling berhubungan. Emosi yang muncul pada mereka merupakan rangkaian kejadian dimulai dari faktor pencetus kemudian dilanjutkan dengan kondisi emosi dan fisiologis yang muncul dan akhirnya perilaku yang tampak sebagai akibatnya.

Plutchik (2003, dalam Pradiwanti, 2006) menjelaskan mengenai proses terjadinya dinamika emosi yang mengikuti alur feedback loops antara lain: 1) stimulus event yang merupakan sesuatu yang tidak diharapkan atau kejadian yang tidak biasa baik datangnya dari eksternal maupun internal; 2) inferred cognition adalah proses penginterpretasian secara kognitif agar individu dapat menangkap makna; 3) psychological arousal merupakan reaksi mekanisme pengaktifan dari sistem saraf simpatetik yang terlibat dalam emosi; 4) feeling state ialah kondisi yang dirasakan saat mengalami suatu emosi dimana; 5) impulse to action merupakan dorongan untuk bertindak yang tampak melalui otot-otot yang menegang, ekspresi wajah, mengepalkan tangan atau tampak seperti bersiap lari, menyerang, berteriak dan lain sebagainya; 6) overt behavior merupakan tindakan yang dilakukan seseorang karena adanya dorongan; dan 7) effect yang berfungsi untuk mengembalikan kita pada kondisi seimbang ketika emosi yang menyebabkan suatu tindakan menurun intensitasnya.

Penelitian ini bertujuan untuk menggambarkan dinamika emosi pada anak dengan 
gangguan autisme menggunakan panduan dari teori emosi feedback loops-nya Plutchik. Teori ini dipilih karena dapat memandu peneliti untuk mendeskripsikan apa saja jenis emosi yang muncul pada anak autis dan bagaimana dinamikanya.

\section{METODE}

Penelitian dilaksanakan dengan pendekatan kualitatif dan rancangan studi kasus. Metode studi kasus ini dipilih karena penelitian ini bermaksud untuk memahami fenomena tentang apa yang dialami oleh subjek penelitian misalnya perilaku, persepsi, motivasi, tindakan, dan lain-lain, secara holistik dan dengan cara deskripsi dalam bentuk kata-kata dan bahasa, pada suatu konteks khusus yang alamiah (Moelong, 2006). Unit analisis dalam penelitian ini adalah dinamika emosi. Peneliti ingin mempelajari gambaran dinamika emosi pada anak autis dan faktor-faktor apa yang mempengaruhi dinamika emosi tersebut serta penanganan emosi anak autistik. Untuk dapat mengenali dinamika emosi pada anak autistik, dalam hal ini penulis menggunakan jenis studi kasus intrinsik. Penelitian dilakukan untuk memahami secara utuh kasus tersebut, tanpa harus dimaksudkan untuk menghasilkan konsep-konsep atau teori ataupun tanpa upaya menggeneralisir (Poerwandari, 2005).

\section{Partisipan}

Pemilihan partisipan dalam penelitian ini dilakukan berdasarkan kriteria tertentu (purposif), yakni dengan memilih individuindividu yang memenuhi kriteria berikut: memiliki karakteristik gangguan autism yang diperkuat dengan diagnosis ahli; diijinkan oleh orang tua dan guru ahli untuk diteliti; dan merupakan siswa di Sekolah dan Pusat Terapi Anak Berkebutuhan Khusus Cita Hati Bunda Sidoarjo. Dua anak autistik laki-laki yang berusia 9 dan 10 tahun berhasil direkrut menjadi partisipan utama penelitian.
Partisipan pendukung adalah significant others dari dua subjek tersebut, yaitu orang tua mereka, terapis mereka, dan penanggung jawab terapis.

\section{Teknikpengumpulan data}

Data penelitian ini dikumpulkan dengan teknik wawancara, observasi dan dokumen. Wawancara yang dilakukan adalah wawancara mendalam (depth interview) dengan petunjuk umum. Jenis wawancara ini mengharuskan pewawancara membuat kerangka dan garis besar pokok-pokok yang ditanyakan namun tidak perlu ditanyakan secara berurutan. Wawancara terutama dilakukan terhadap significant others, yaitu orang tua, penanggung jawab terapis dan terapis dari kedua subjek utama.

Teknik observasi menjadi alat pengumpul data utama untuk meneliti dua anak autistik yang menjadi subjek inti penelitian ini. Jenis observasi dalam penelitian ini adalah observasi partisipan, di mana peneliti turut ambil bagian dalam kegiatan anak autistik yang diteliti. Observasi partisipan ini memungkinkan peneliti dapat berinteraksi dan berkomunikasi secara akrab dan leluasa dengan subjek, sehingga memungkinkan adanya pengamatan yang lebih rinci dan detail. Alat observasi yang digunakan adalah catatan berkala dan check list. Dengan catatan berkala, peneliti berinteraksi dengan subjek penelitian dalam jangkawaktu tertentu, kemudian menuliskan kesan-kesan umumnya, setelah itu peneliti menghentikan penyelidikannya dan mengadakan penyelidikan lagi pada saat lain dengan cara yang sama seperti sebelumnya. Sementara check list yang digunakan adalah sebuah daftar yang berisi nama-nama subjek dan faktor-faktor emosi yang hendak diselidiki. Sumber data lain yang digunakan adalah dokumen. Dokumen didapatkan dari hasil pemeriksaan dan hasil terapi yang dilakukan oleh terapis pada kedua subjek penelitian. 


\section{Teknik analisis data}

Teknik analisis data yang digunakan pada penelitian ini adalah analisis tematik dengan melakukan koding hasil transkip wawancara yang telah di verbatim. Koding adalah dua aktivitas yang dilakukan secara simultan: reduksi data secara mekanis dan kategorisasi data secara analitis ke dalam tema-tema (Neuman, 2000).

Penelitian ini menggunakan teknikteknik pemeriksan keabsahan dengan teknik ketekunan pengamatan, triangulasi serta uraian rinci. Moleong (2006) mengatakan bahwa ketekunan pengamatan bermaksud menemukan ciri-ciri dan unsur-unsur dalam situasi yang sangat relevan dengan persoalan atau isu yang sedang dicari dan kemudian memusatkan diri pada hal-hal tersebut secara rinci. Triangulasi adalah teknik pemeriksaan keabsahan data yang memanfaatkan sesuatu yang lain di luar data itu untuk keperluan pengecekan atau sebagai pembanding terhadap data tersebut (Moleong, 2006). Sedangkan uraian rinci merupakan teknik yang menuntut peneliti agar melaporkan hasil penelitiannya seteliti dan secermat mungkin hingga dapat menggambarkan proses dan tempat penelitian diselenggarakan (Moleong, 2006).

\section{HASILDAN PEMBAHASAN}

Studi ini memperlihatkan bahwa kedua subjek penelitian yang telah didiagnosa sebagai anak autistik memang mempunyai karakteristik yang berbeda dengan anak-anak lain dalam mengalami dan mengekspresikan emosi-emosi positif dan negatif. Gangguan yang dimiliki kedua subjek membuat emosi mereka mudah sekali bergejolak ditambah lagi dengan adanya stimulus yang kedatangannya tidak terduga dan subjek tidak dapat mengontrol keberadaan pencetus tersebut, sehingga mereka pun melampiaskan emosinya dengan cara yang bisa mereka lakukan. Secara umum dinamika emosi pada kedua subjek anak autistik yang menjadi partisipan dalam penelitian ini dapat digambarkan dalam tabel berikut:

Tabel 1. Dinamika emosi subjek 1 dan 2

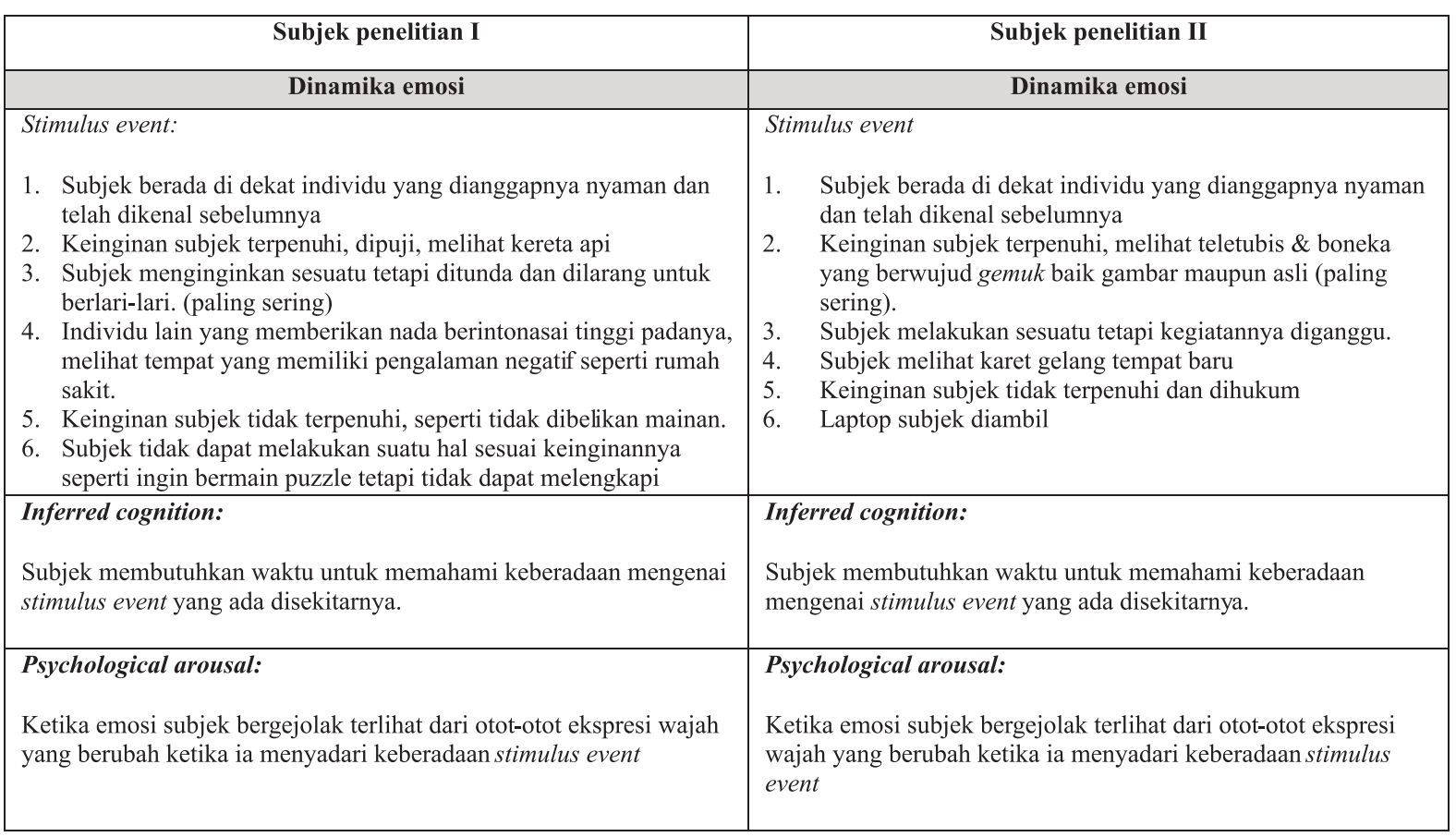




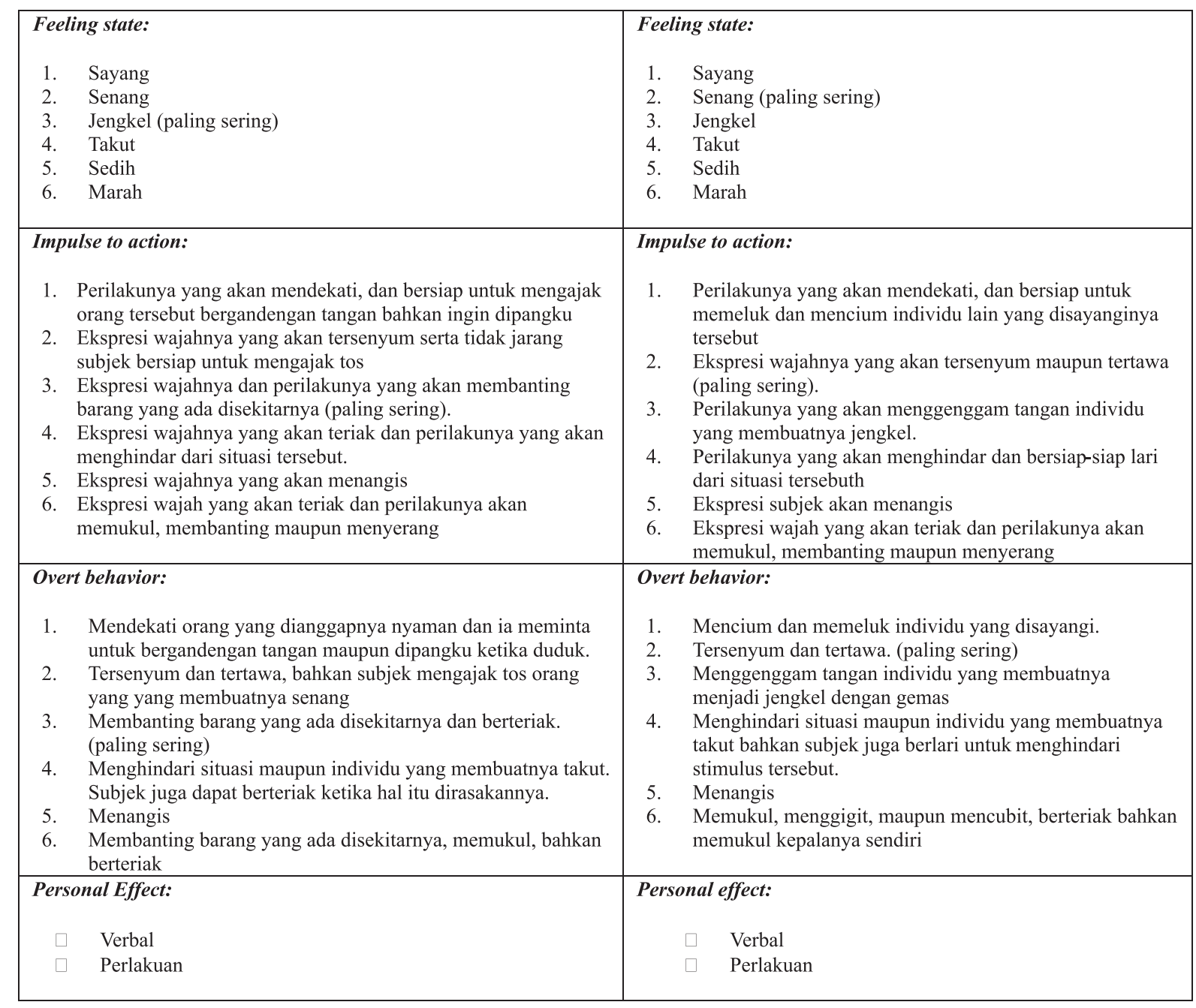

\section{Stimulus Event}

Stimulus event merupakan sesuatu yang tidak diharapkan atau kejadian yang tidak biasa baik eksternal maupun internal, dapat mengubah level afeksi dan perilaku seseorang (Weisman dalam Plutchik, 2003). Pada anak autistik, banyak stimulus yang menjadi pencetus emosi mereka. Terlebih lagi terkait dengan karakteristik yang dimiliki anak autistik yaitu gangguan pada sensori, persepsi, komunikasi dan interaksi yang membuat mereka kebingungan dengan adanya stimulus tersebut.

\section{Subjek 1}

Pada subjek satu (I), ada beberapa stimulus event yang membuat subjek memunculkan emosinya. Penyebab emosi subjek berkaitan dengan individu lain, situasi maupun benda.

Stimulus event berasal dari individu lain. Subjek dapat merasa nyaman dengan individu yang telah dikenalnya. Namun, tidak semua individu yang telah dikenalnya dapat membuat nyaman. Nyaman yang dimaksud disini, subjek tidak merasa asing dengan individu tersebut dan subjek merasa akrab terlebih lagi jika individu tersebut menuruti keinginan subjek. Subjek merasakan ini dimanapun dia berada. Subjek mengerti mana individu yang menyukainya dan yang tidak menyukainya.

Stimulus event berasal dari situasi. Stimulus ini berkaitan dengan keinginan 
subjek yang terpenuhi. Keinginan ini bermacam-macam. Keinginan subjek yang sering di minta adalah hal yang sedarhana, yaitu menannyakan keberadaan ibunya dan ingin bertemu dengannya. Stimulus dari situasi juga ada yang berbentuk pujian. Subjek menyukai suatu pujian yang ditujukan padanya. Biasanya hal ini diberikan sebagai reward karena subjek berhasil melakukan sesuatu sesuai perintah. Baik itu perintah dalam proses terapi maupun perintah lain seperti ketika memainkan game playstation.

Nada tinggi yang ditujukan untuk subjek juga situasi yang menjadi stimulus emosi. Subjek sensitif dengan nada tinggi. Hal ini tidak memandang siapa yang memberikan nada dengan intonasi tinggi baik itu orang terdekatnya maupun orang yang belum dikenalnya maka ia akan tetap mengekspresikan emosinya. Ketika subjek diberi nada dengan intonasi tinggi, membuatnya kaget sehingga membutuhkan pelampiasan atas kegundahan perasaannya. Situasi lain yang memicu emosi adalah tempat yang menjadi konteks pengalaman kurang menyenangkan subjek seperti rumah sakit. Subjek hafal bagaimana ciri-ciri rumah sakit yang pernah dikunjunginya, jika mirip subjek langsung mengekspresikan emosi negatifnya, berupa menghindar dan berteriak-teriak.

Stimulus event berasal dari benda. Benda yang dimaksud disini adalah kereta api. Kereta api yang memancing emosi subjek dapat berupa kereta api yang berwujud asli maupun kereta api yang berbentuk mainan dan gambar.

\section{Subjek 2}

Pertama, stimulus event berasal dari individu lain. Yang dimaksud individu lain disini adalah individu yang dirasa nyaman bagi subjek. tidak berbeda dengan subjek I yang juga merasakan ini. Subjek II juga merasa nyaman dengan orang yang telah dikenalnya tetapi tidak semua orang yang telah dikenalnya membuat ia merasa nyaman. Hal ini dilakukan kapanpun dan dimanapun dia berada ketika ia bertemu dengan orang tersebut. Inididu lain disini dalam kehidupan subjek adalah keluarga subjek dan salah satu terapis. Stimulus event ini membeuat emosi subjek bergejolak, terlebih lagi jika orang tersebut menuruti keinginannya.

Kedua, stimulus event berasal dari situasi. Situasi yang dimaksud adalah keinginan subjek terpenuhi. Keinginan ini beragam, antara lain ketika ia ingin menangkap lalat dan berhasil menangkap lalat yang dilihatnya. Situasi yang lain adalah ketika subjek melakukan sesuatu tetapi kegiatannya diganggu. Hal ini berlangsung bagi setiap aktivitas yang dilakukannya. Ketika terapis membenarkan posisinya yang awalnya tiduran menjadi duduk juga dapat menjadi pencetus. ketika kegiatannya terhambat seperti ketika subjek diperintah terapis untuk pindah tempat duduk maupun mengambil suatu barang ketika ia sedang melakukan sesuatu juga menjadi pencetus emosinya seperti ketika subjek sedang melihat teletubbies di laptopnya, tetapi diperintah oleh terapis untuk mengambil sesuatu seperti gelas, piring di dapur maupun yang lainnya. Subjek juga tidak dapat jauh dari laptopnya karena ia sangat menyukai teletubbies yang dapat dilihatnya dari laptop tersebut. Hal ini berkaitan dengan kemampuan subjek II dalam mempersepsi sesuatu dan keadaan mood dalam dirinya. Terlebih lagi ia memiliki kesulitan dalam berkomunikasi dengan lingkungannya sehingga ia tidak dapat menyampaikan maksud yang diinginkannya.

Subjek II memiliki lantai favorit yang digunakan sebagai tempat duduknya ketika ia mengikuti kelas klasikal. Jika subjek duduk di tempat itu, biasanya diperintah oleh terapis untuk pindah tempat duduk ke tengah ruangan karena badan subjek yang besar dapat menghalangi orang lain yang akan masuk. Ketika subjek di perintah pindah oleh terapis, hal ini lah yang menjadi pencetus emosi subjek bergejolak. Emosi subjek juga bergejolak adalah ketika ia menemui tempat 
baru yang dianggapnya asing. Subjek memiliki karakteristik kesulitan untuk beradaptasi dengan suatu lingkungan yang baru.

Ketiga, stimulus event berasal dari benda. Benda yang dimaksud adalah laptop. Subjek II selalu membawa kemana-mana laptopnya. Hal ini dilakukan karena dengan adanya laptop subjek dapat membuka file teletubbies setiap saat. Subjek menyukai teletubbies, baik berwujud boneka maupun hanya gambar sehingga benda yang paling diminati oleh subjek adalah laptop. Mulai subjek kecil, ia menyukai teletubbies. Selain teletubbies, subjek juga menyukai boneka yang wujudnya gemuk. Hal ini dapat berupa boneka asli maupun hanya berupa gambar. Benda lain yang memicu emosi adalah karet gelang. Subjek II pernah mengalami pengalaman yang kurang menyenangkan dengan karet gelang. Ia pernah terkena jepretan karet gelang sehingga ia menghindar ketika ada karet gelang dihadapannya.

Pada subjek penelitian I stimulus yang paling sering dirasakan adalah ketika ia dilarang untuk berlari-lari. Hal ini merupakan kegiatan yang disuka dan seringkali dilakukan subjek. Pada subjek penelitian II stimulus yang paling sering dirasakan adalah ketika ia melihat teletubbies baik yang berwujud asli maupun gambar. Teletubbies adalah kesukaan subjek. hal ini seringkali dilihat oleh subjek dari laptopnya. Peneliti juga menemukan ternyata tidak hanya stimulus event saja yang membuatnya memunculkan emosi, tetapi hal ini berkaitan dengan karakteristiknya sebagai anak autistik sehingga membuatnya kurang dapat menyampaikan dan menyalurkan emosinya dengan tepat pada lingkungannya. Dengan begitu kejadian-kejadian yang dialami oleh kedua subjek seperti diatas tersebut merupakan hal yang mengawali munculnya dinamika emosi pada anak autistik.

\section{Inferred Cognition}

Menurut Plutchik, kejadian yang tidak diharapkan individu tidak akan bermakna jika tidak ada interpretasi kognitif. Diasumsikan stimulus kejadian baik internal maupun eksternal tidak bertindak sebagai pencetus utama yang mengawali jalannya proses emosi, tetapi peristiwa butuh diinterpretasikan agar individu dapat menangkap maknanya (Plutchik, 2003).

Pada subjek satu (I) dalam menginterpretasikan stimulus yanga ada, ia membutuhkan waktu untuk memahami keberadaan mengenai stimulus event yang ada disekitarnya tesebut. Subjek menyadari adanya stimulus event tersebut, tetapi subjek membutuhkan waktu untuk memahami apa makna dari adanya stimulus event tersebut.

Anak autistik memiliki karakteritik tersendiri yang berbada dari anak normal lainnya. Mereka memiliki gangguan pada bagian sensori dan persepsi sehingga ini juga yang menyebabkan subjek lebih lama dan membutuhkan waktu untuk berpikir mengenai stimulus event yang hadir dibandingkan dengan anak-anak lain.

Pada subjek dua (II) juga terjadi hal yang sama. Subjek tidak dapat merespon secara langsung keberadaan stimulus tersebut, tetapi ia membutuhkan waktu paling lama 30 detik untuk memahaminya. Hal ini terjadi karena subjek II juga memiliki gangguan dalam sensori dan persepsi. Dalam diri subjek sendiri terjadi kebingungan, ia tidak mengetahui apa yang harus ia lakukan sehingga tindakannya tepat karena subjek hanya dapat melakukan perilaku yang dapat dilakukannya karena ia tidak mengetahui tindakan itu tepat atau tidak.

Pada subjek satu (I) dan subjek dua (II), keduanya membutuhkan waktu untuk memahami keberadaan stimulus yang ada. Mereka tidak dapat merespon secara reflek keberadaan stimulus tersebut, hal ini terkait dengan gangguan yang dimiliki kedua subjek yaitu pada bagian sensori dan persepsi. Namun demikian waktu yang dibutuhkan untuk memahami stimulus tersebut tidaklah terlalu lama. Pada subjek dua(II) dalam waktu 
tidak lebih dari 30 detik, sudah dapat memahami.

Lamanya subjek dalam memahami stimulus selain dipengaruhi oleh gangguan yang dimiliki juga terkait dengan kebiasaan. Semakin terbiasa subjek dengan stimulus maka makin cepat subjek dalam memahami keberadaan stimulus tersebut.

\section{Feeling State}

Plutchik membagi emosi menjadi delapan emosi dasar, yaitu: fear (takut), anger (marah), sadness (sedih), joy (gembira), acceptance (antisipasi), surprise (terkejut) (Plutchik, 2003). Kedelapan emosi dasar yang dikatakan Plutchik tersebut beberapa dirasakan oleh subjek. Perasaan takut, jengkel, marah, sedih, senang dan sayang dirasakan oleh kedua subjek. Subjek juga merasa takut ketika ia mengunjungi tempat yang memiliki pengalaman kurang menyenangkan untuknya, seperti rumah sakit. Subjek pernah sakit dan di rawat di rumah sakit, sehingga membuat subjek takut dengan tempat itu. Subjek juga merasakan hal yang sama ketika ketika ia akan dihukum. Ketika subjek diberi tahu bahwa ia akan dihukum di ruang gelap atau tidak mengikuti outing, ia merasa ketakutan, subjek merasa tidak nyaman dengan ruangan kosong gelap. Subjek menyukai outing, sehingga ketika ia tidak diijinkan untuk mengikuti outing yang diadakan tiap minggu, ia merasa takut. Kemudian, subjek juga merasa takut ketika ia bertemu maupun harus berinteraksi dengan orang yang tidak menyukainya. Terlebih lagi jika orang tersebut memberikan pengalaman kurang menyenangkan pada subjek.

Pada subjek satu (I) ketika berada di dekat individu yang membuatnya nyaman membuatnya merasa sayang. Individu ini adalah individu yang telah dikenal sebelumnya. Subjek mengetahui individu yang menyukainya maupun tidak menyukainya. Tidak semua individu yang dikenalnya dapat membuatnya nyaman. Subjek biasanya menunjukkan rasa sayang pada Ibu dan salah satu terapis yang telah mengenalnya lama.
Pada subjek dua (II) ketika subjek menemui karet gelang ia merasa ketakutan. Hal ini dirasakan subjek karena ia memiliki pengalaman yang kurang menyenangkan terhadap karet gelang yaitu terkena jepretan karet gelang sehingga menyebaban ia merasa takut setiap kali melihat karet gelang walaupun itu tidak dijepretkan padanya. Dengan takutnya subjek pada karet gelang, terapis biasanya menggunakan benda ini sebagai hukuman ketika subjek tidak mau menjalankan perintah dalam terapi tetapi karet gelang tersebut tidak dijepretkan pada subjek, terapis hanya membawa karet gelang saja subjek sudah merasa takut. Subjek dua (II) merasakan takut juga ketika ia mengunjungi tempat yang baru. Subjek merasa asing dengan tempat yang baru ditemuinya. Subjek sebagai anak autistic memiliki karakteristik yang tidak menyukai adanya perubahan. Hal ini dilakukannya karena subjek kesulitan dalam beradaptasi dengan lingkungan yang baru ia temui.

Ada tiga hal yang membuat subjek dua (II) merasa marah. Pertama, ketika laptop subjek diambil. Laptop adalah benda kesayangan subjek karena dengan laptopnya, ia dapat melihat teletubbies. Subjek menyukai teletubbies sejak ia kecil. Kedua, ketika apa yang subjek pegang diambil ketika ia melakukan aktivitas. Hal ini terjadi ketika subjek diperintah pindah tempat diduduk oleh terapis pada saat itu subjek sedang mencoratcoret kertas, kemudian kertas subjek diambil oleh terapis agar ia pindah tempat duduk. Ketiga, ketika subjek menunggu loading laptopnya juga ia mengekspresikan perasaan yang sama. Loading laptop ini ketika sedang membuka file teletubbies-nya. Perasaan subjek mengenai hal-hal ini lebih bertahan lama dibanding perasaan yang lain.

Subjek dua (II) dapat merasa jengkel ketika subjek melakukan sesuatu tetapi aktivitasnya diganggu. Subjek merasakan hal tersebut ketika diperintah terapis untuk membenarkan posisi tempat duduknya yang awalnya tiduran menjadi posisi duduk yang 
benar sehingga badan terapis seringkali disandarkan pada badan subjek untuk mencegah subjek kembali tiduran. Kedua, ketika subjek sedang melihat teletubbies dilaptopnya tetapi disuruh oleh terapis mengambil sesuatu seperti galas atau piring di dapur. Hal ini membuat subjek merasa jengkel.

Subjek dua (II) merasa sedih ketika keinginannya tidak dipenuhi seperti subjek tidak diijinkan terapis untuk duduk di lantai depan kelas klasikal ketika kelas klasikal berlangsung maupun ketika makan siang di kelas klasikal. Subjek memiliki tempat favorit di lantai depan pintu kelas klasikal. Hal lain yang membuatnya mengekspresikan sama adalah ketika subjek dihukum karena subjek melakukan suatu kesalahan. Subjek mulai mengetahui jika ia melakukan kesalahan. Hal ini biasanya diberi tahu oleh orang-orang disekitarnya. Subjek mengetahui ini karena proses pembiasan yang telah dilakukan sehingga ketika ia melakukan kesalahan sudah mengetahui.

Ada tiga hal yang membuat subjek merasa senang. Pertama, ketika subjek melihat teletubbies, baik itu berwujud boneka asli maupun hanya berupa gambar. Subjek sangat menyukai boneka teletubbies sejak ia kecil. Kedua, tidak hanya teletubbies saja yang membuatnya senang, boneka lain yang wujudnya gemuk juga dapat membuatnya senang. Ketiga, ketika subjek melihat temannya berhasil menangkap bola dan melihat temannya bernyanyi.

Subjek dua (II) juga dapat merasa sayang ketika ia berada di dekat individu yang membuatnya nyaman. Individu ini adalah individu yang telah dikenal sebelumnya. Tidak semua orang yang dikenalnya dapat membuatnya nyaman. Subjek seringkali menunjukkan rasa sayang pada keluarga dan salah satu terapis. Kedua subjek dapat merasakan takut, jengkel, marah, sedih, senang dan sayang dengan stimulus yang berbeda walaupun ada beberapa stimulus yang sama. Rasa sayang dengan stimulus yang sama muncul pada kedua subjek yakni berasal dari individu lain yang dianggap nyaman. Keduanya tidak mudah menanggap individu lain sebagai orang yang nyaman karena tidak semua individu yang telah dikenalnya dapat menjadi nyaman di mata kedua subjek.

Emosi jengkel pada subjek I menjadi emosi yang paling sering dirasakan. Hal ini disebabkan karena subjek sangat menyukai lari-lari dalam segala aktivitasnya. Aktivitas tersebut seringkali dilarang oleh orang-orang disekitar subjek sehingga membuatnya merasakan emosi jengkel lebih sering daripada emosi yang lain. Emosi senang pada subjek II menjadi emosi yang paling sering dirasakan. Hal ini disebabkan karena subjek sangat menyukai teletubbies yang dilihatnya dari laptop. Subjek tidak dapat dipisahkan dari laptopnya. Ia melihat teletubbies dari laptopnya setiap saat sehingga ketika ia melihat teletubbies, menjadi sering merasakan emosi senang daripada emosi yang lain.

\section{Psychological arousal}

Psychological arousal akan tampil bersamaan dengan pengalaman emosional yang dialami oleh seseorang (Canon, 1929 dalam Haber \& Runyon, 1984: 110). Psychological arousal yang tampil akan sangat tergantung pada jenis emosi yang muncul serta intensitasnya. Emosi negatif yang kuat seperti marah dan takut menyebabkan perubahan besar yang melibatkan setiap sistem kekebalan tubuh (Haber \& Runyon, 1984:109). Setiap individu akan menunjukkan reaksi fisiologis yang berbedabeda terhadap sebuah emosi (Davidoff, 1991: 53). Oleh karena itu ketika subjek mengalami kondisi emosional tertentu juga berpengaruh pada kondisi fisiknya, pada kedua subjek semuanya mengalami respon fisiologis yang sama ketika mendapatkan stimulus yakni terlihat dari ekspresi wajahnya yang berubah.

Kedua subjek merupakan anak autistik yang memiliki karakteristik berbeda dari anak 
normal lainnya, sehingga perubahan fisiologis yang terlihat dari kedua subjek juga minim. Anak autistik cenderung dengan lemahnya respon terhadap sesuatu. Pada kedua subjek reaksi fisiologi terlihat dari ekspresi wajahnya ketika mendapatkan stimulus baik positif maupun negatif selalu ada perubahan dari ekspresi wajahnya.

Kontrol pikiran sangat penting dilakukan oleh individu untuk selalu menjaga kondisi tubuhnya begitu juga pada anak autistic walaupun mereka memiliki gangguan dalam bidang ini, pengaruh lingkungan sangat dibutuhkan agar mereka mampu mengendalikan pikirannya ketika menghadapi suatu stimulus.

Pada akhirnya anak autistik tidak akan dapat menjadi normal seperti anak-anak lain, tetapi anak autistik tetap dapat mengendalikan pikirannya jika itu dilatih secara terusmenerus. Emosi positif yang dihasilkan dapat mengembalikan kondisi tubuh pada keadaan seimbang.

\section{Impulse to action}

Dorongan untuk bertindak (impulse to action) ini biasanya tampak pada menegangnya otot-otot ekspresi wajah, mengepalkan tangan atau bersiap (kondisi fisik) untuk lari, menyerang, berteriak dan lain-lain (Plutchik, 2003). Dari penjelasan ini terlihat bahwa yang dimaksud dengan dorongan untuk bertindak itu bersifat "tampak" secara fisik. Oleh karena itu tidak dapat dijelaskan secara deksriptif. Sehingga, dorongan pada kedua subjek untuk melakukan perilaku tampak dari mereka.

Pada subjek satu (I) ketika merasa takut terlihat dari ekspresi wajahnya yang akan teriak dan perilakunya yang akan menghindar dari situasi tersebut. Hal yang sama juga terjadi pada subjek dua (II), dorongan untuk bertindak terlihat perilakunya yang akan menghindar dan bersiap-siap lari dari situasi tersebut.

Dorongan untuk bertindak ketika kedua subjek merasakan emosi marah, tampak dari ekspresi wajah yang akan teriak dan perilakunya akan memukul, membanting maupun menyerang individu yang ada disekitarnya. Bahkan pada subjek dua (II) ia juga tidak ragu akan memukul kepalanya sendiri.

Pada subjek satu (I) dorongan untuk bertindak ketika emosi jengkel tampak dari ekspresi wajahnya dan perilakunya yang akan membanting barang yang ada disekitarnya. Sedangkan pada subjek dua (II) terlihat dari perilakunya yang akan menggenggam tangan individu yang membuatnya jengkel. Terjadi kesamaan pada kedua subjek ketika merasa sedih, dorongan untuk bertindaknya terlihat pada ekspresi wajahnya yang akan menangis. Dorongan untuk bertindak yang sama juga terjadi pada kedua subjek ketika merasa senang yang dapat terlihat dari ekspresi wajahnya yang akan tersenyum maupun tertawa.

Pada subjek satu (I) dan subjek dua (II) ketika merasa sayang terlihat pada perilakunya yang akan mendekati. Pada subjek satu (I) dilanjutkan dengan bersiap untuk mengajak individu tersebut bergandengan tangan serta bersiap untuk dipangku oleh individu tersebut. Pada subjek dua (II) dilanjutkan dengan bersiap untuk memeluk dan mencium individu lain yang disayanginya tersebut.

Pada subjek penelitian I karena emosi yang paling sering muncul adalah emosi jengkel, maka setiap kali ia merasa jengkel subjek terlihat akan membanting barang yang ada disekitarnya dan terlihat dari ekspresinya wajahnya akan berteriak. Pada subjek penelitian II emosi yang paling sering muncul adalah senang sehingga terlihat subjek akan tertawa dan tersenyum dari ekspresi wajahnya.

\section{Overt behavior}

Overt behavior merupakan tindakan yang dilakukan oleh individu karena adanya impulse to action yang terjadi sebelumnya. Langkah ini dilakukan agar subjek kembali pada keadaan semula (homeostatis). Menurut 
Weisman (dalam Plutchik, 2003) mengatakan bahwa fungsi afek adalah untuk mengembalikan kita pada kondisi seimbang atau dengan kata lain tindakan yang berhubungan dengan emosi dapat mengurangi emosi yang menyebabkannya.

Dalam menunjukkan rasa takutnya kedua subjek menghindari situasi maupun individu yang membuatnya takut. Pada subjek satu (I) perilakunya disertai dengan berteriak ketika hal itu dirasakannya. Pada subjek dua (II) disertai dengan berlari ketika menghindari stimulus tersebut.

Pada subjek satu (I) ketika dirinya merasa marah, subjek membanting barang yang ada disekitarnya, memukul. Hal yang tidak jauh berbeda juga dilakukan subjek dua (II). Ia memukul, menggigit, maupun mencubit, bahkan memukul kepalanya sendiri ketika ia sedang merasakan marah. Keduanya sama-sama berteriak ketika merasakan emosi ini.

Hal yang berbeda dilakukan ketika mereka merasa jengkel. Pada subjek satu (I), ia membanting barang yang ada disekitarnya dan berteriak. Sedangkan pada subjek dua (II) ia menggenggam tangan individu yang membuatnya menjadi jengkel dengan gemas. Hal-hal ini dilakukan ketika mereka merasa jengkel dengan siapapun.

Kedua subjek melakukan perilaku yang sama ketika ia merasa sedih yaitu dengan menangis. Ketika merasa senang, kedua subjek juga melakukan perilaku yang sama yaitu tersenyum dan tertawa. Tetapi pada subjek satu (I) disertai dengan mengajak inidvidu lain yang diajak berinteraksi dengannya untuk tos.

Ketika kedua subjek merasa sayang, perilaku yang dilakukan adalah mendekati individu yang dianggapnya sayang. Pada subjek satu (I), ia meminta untuk bergandengan tangan maupun dipangku ketika duduk. Pada subjek dua (II), selain mendekat ia juga mencium serta memeluk individu lain yang disayanginya tersebut.
Pada subjek penelitian I, emosi yang paling sering muncul adalah jengkel sehingga perilakunya membanting barang yang ada di sekitarnya dan berteriak. Pada subjek penelitian II emosi yang paling sering muncul adalah emosi senang sehingga perilakunya tersenyum dan tertawa.

\section{Effect}

Efek merupakan kondisi yang ingin dicapai oleh subjek untuk menetralisir stimulus yang dialami oleh subjek terutama stimulus yang tidak menyenangkan. Untuk mengembalikan pada kondisi homeostatis, dilakukan proses feedback loops. Karena feedback loops dapat mempengaruhi dorongan untuk bertindak, kondisi perasaan, dan kognisi, sesuai stimulus yang diberikan. Perasaan dan perilaku dapat mempengaruhi sama seperti kognisi mempengaruhi perasaan (Plutchik, 2003). Efek yang diberikan pada kedua subjek adalah effect personal yaitu dengan memberikan hikmah pada individu.

Pada anak autistik tidak dapat dilakukan hal seperti meditasi karena mereka sendiri kesulitan untuk fokus pada satu hal, sehingga mereka diberikan terapi perilaku. Terapi perilaku ini berupa verbal maupun perlakuan. Pemberian secara perlakuan dilakukan jika secara verbal tidak mengatasi perilaku subjek akibat emosinya. perlakuan ini dapat berupa punishment. Punishment ini berupa timeout yang diberikan pada subjek. Subjek dibiarkan dalam suatu ruangan kosong sendiri dengan hal inilah ia dapat mengendalikan emosinya.

Dalam memberi pengajaran pada subjek untuk dapat mengontrol emosinya adalah dengan pembiasaan. Pembiasaan yang dimaksud ini adalah dengan cara berulangulang dengan maksud, kedua subjek lebih mudah dalam memahami. Faktor penyebab emosi pada kedua subjek terdiri dari benda, situasi dan individu lain. Ketiganya sangat berpengaruh bagi munculnya emosi kedua subjek. Dengan rincian pada subjek satu (I) situasi sebanyak 8 , benda sebanyak 1 , dan 
individu lain sebanyak 2. Pada subjek dua(II), situasi sebanyak 6 , benda 2 dan individu lain 1. Dengan rincian tersebut terlihat bahwa factor situasi cenderung mendominasi dalam memunculkan emosi pada kedua subjek.

Ketika subjek mengekspresikan emosi tidak terpaut pada tempat tertentu walaupun pada subjek satu (I) memiliki tempat yang dapat memunculkan emosi yaitu tempat yang memiliki pengalaman negatif pagi subjek. pada subjek dua (II) tempat yang baru ditemuinya juga dapat memunculkan emosinya. hal ini bukan berarti kedua subjek hanya memunculkan emosi pada tempat tersebut, tetapi setiap mereka merasakan adanya stimulus, ia akan mengekspresikan tanpa melihat dimana tempat saat itu.

Untuk waktu yang dibutuhkan kedua subjek dalam mengekspresikan emosi juga tidaklah berlangsung lama. Hal ini sama dengan anak-anak lain. Namun yang berbeda terlihat ketika mereka mengeskpresikan emosi marah yang berlangsung lebih lama dari emosi lain. Pada subjek satu (I) emosi ini dapat berlangsung hingga sehari penuh terutama jika pencetusnya adalah nada dengan intonasi tinggi. Dalam memunculkan emosi kedua subjek tidak memperhatikan waktu (jam-jam) tertentu tetapi sehingga tidak ada waktu pasti kapan mereka memunculkan emosi. Hal ini bergantung pada kehadiran stimulus.

\section{SIMPULAN}

Berdasarkan hasil analisis dan pembahasan, ditemukan sesuatu yang berlaku sama pada kedua subjek antara lain ialah adanya stimulus berupa individu lain yang dianggapnya nyaman dan ketika kegiatan mereka diganggu. Proses interpretasi dan pemaknaan stimulus juga berlaku sama pada kedua subjek. Mereka membutuhkan waktu untuk memahami keberadaan stimulus tersebut. Kemudian pada reaksi fisiologis juga ditemukan sesuatu yang berlaku sama yakni keduanya memberikan perubahan pada ekspresi wajahnya ketika merasakan stimulus yang ada.

Selain itu munculnya emosi takut, marah, jengkel, sedih, senang, sayang pada kedua subjek, dimana emosi sedih, takut, marah merupakan beberapa dari delapan emosi dasar yang kemukakan Plutchik (2003). Pada rasa sedih, senang, takut, dan sayang memunculkan perilaku yang nampak sama, sedangkan rasa marah dan jengkel ditunjukkan dengan perilaku yang berbedabeda pada kedua subjek. Selanjutnya pada bagian effect juga terjadi hal yang sama pada kedua subjek yaitu dengan pemberian terapi perilaku baik secara verbal maupun perlakuan.

Dinamika emosi yang dialami oleh anak autistik disebabkan oleh tiga faktor penyebab. Faktor penyebab tersebut antara lain benda, situasi dan individu lain. Pada kedua subjek penelitian yang menjadi faktor penyebab terbanyak ialah situasi. Dinamika emosi yang terjadi pada anak autistik merupakan rangkaian dari beberapa komponenkomponen emosi yakni stimulus event, inferred cognition, psychological arousal, feeling state, impulse to action, overt behavior dan effect personal.

Berdasarkan hasil penelitian diatas, peneliti menyadari terdapat kelemahan dalam teori yang digunakan. Teori emosi feedback loops evolutionary dari Plutchik lebih melihat pada perilaku yang tampak (overt behavior), sehingga apa yang tidak tampak yakni proses pemaknaan tidak dapat dijelaskan oleh teori tersebut. Pada kedua subjek ditemukan bahwa mereka membutuhkan waktu dalam memahami keberadaan stimulus yang ada. Tetapi bagaimana proses pemaknaan dari stimulus tersebut tidak dapat dijelaskan. 


\section{DAFTAR PUSTAKA}

Castelli, F. (2005). Understanding Emotions from Standardized Facial Expression in Autism and Normal Development. dalam situs: Sage Publication and National Autistic Society, www.sagepublication.com.diakses tanggal 20 Desember 2010

Davidoff. (1991). Psikologi Suatu Pengantar (Edisi kedua Jilid 2). Jakarta: Erlangga

Greenspan, S.T \& Wieder, S. (2006). The Child with Special Needs (Anak Berkebutuhan Khusus).(Terjemahan). Jakarta: Yayasan Ayo Main

Haber \& Runyon. (1984). Psychology of Adjustment.Illnois: The Dorsey Press

Maria,Cristina.(2009).http://melaticeria.or.id/ind ex.php?option $=$ com content $\&$ task $=$ view \& $\mathrm{id}=20$ \&Itemid $=51$. diakses 7 September 2010

Moloeng, J, Lexy. (2006). Metodologi Penelitian Kualitatif. Bandung: PT Remaja Rosdakarya

Neuman, W. L. (2000). Social Research Methods, Qualitative and Quantitative Approaches. Third Edition. Boston: Pearson Education Inc.
Ornstein, R, \& Cartensen, L. (1991). Psychology: The Study of Human Experience (3th edition). Sandiego:Harcourt Brace Jovonich Publishers

Peeters, T. (2004). Autisme. (Terjemahan) Jakarta: Dian Rakyat

Plutchik, R. (2003). Emotions and Life. Washington DC: American Psychological Association

Poerwandari, K. (2005). Pendekatan Kualitatif untuk Penelitian Perilaku Manusia. Jakarta: Lembaga Pengembangan sarana Pengukuran dan pendidikan psikologi (LPSP3) Fakultas Psikologi Universitas Indonesia.

Wijayakusuma, Hembing. (2009). Autisme, Hiperaktif dan Solusinya. http://autishembingcenter.com. diakses 6 Agustus 2010 